First Peoples Child \& Family Review

An Interdisciplinary Journal Honouring the Voices, Perspectives, and Knowledges of

First Peoples through Research, Critical Analyses, Stories, Standpoints and Media

Reviews

\title{
Torres Strait Island Parents' Involvement in their Children's Mathematics Learning: A Discussion paper
}

\section{Bronwyn Ewing}

Volume 4, Number 2, 2009

URI: https://id.erudit.org/iderudit/1069336ar

DOI: https://doi.org/10.7202/1069336ar

See table of contents

Publisher(s)

First Nations Child and Family Caring Society of Canada

ISSN

1708-489X (print)

2293-6610 (digital)

Explore this journal

Cite this article

Ewing, B. (2009). Torres Strait Island Parents' Involvement in their Children's Mathematics Learning: A Discussion paper. First Peoples Child \& Family Review, 4(2), 129-134. https://doi.org/10.7202/1069336ar

\section{Article abstract}

This paper is a beginning point for discussing what the literature states about parents' involvement in their children's mathematics education. Where possible it will focus on Torres Strait Islander Peoples. Little is known about how Torres Strait Islander parents approach their children's learning of mathematics and how important early mathematics is to mothers. What is known is that is they are keen for their children to receive an education that provides them with opportunities for their present and future lives. However, gaining access to education is challenging given that the language of instruction in schools is written to English conventions, decontextualised and disconnected from the students' culture, community and home language. This paper discusses some of the issues raised in the literature about what parents are confronted with when making decisions about their children's education.
This document is protected by copyright law. Use of the services of Érudit (including reproduction) is subject to its terms and conditions, which can be viewed online.

https://apropos.erudit.org/en/users/policy-on-use/ 


\title{
Torres Strait Island Parents' Involvement in their Children's Mathematics Learning: A Discussion Paper
}

\author{
Bronwyn Ewing ${ }^{a}$
}

${ }^{\text {a }}$ Ph.D., Queensland University of Technology, Brisbane, Queensland, Australia

\section{Situating the "self" in Research}

This discussion paper is the first attempt by the author to put into words her early learnings and understandings of Torres Strait Islander parents' involvement in their children's mathematics education. She is not at the same state of awareness nor understanding of Indigenous Peoples in Australia and therefore does not consider herself an "expert" on Indigenous ways as written by Veronica Arbon (2008) in her book Arlathirnda Ngurkarnda Ityirnda Being-Knowing-Doing. To do this would be offensive to Indigenous Peoples and a substantial breach of trust and respect to purport to be an expert about such matters that she has not experienced. What she is attempting to do is to take small steps to learn about Indigenous parents', particularly women's involvement in their children's mathematics education in the context of the Torres Strait Islands so as to work with this community in environments for mathematics learning. She is non-Indigenous, of Scottish/Irish Catholic heritage, a university educator of Early Childhood mathematics and researcher working with Indigenous communities on ways to enhance the educational opportunities of their young people which continues to be subjected to negative reports in the Australian Press (cf. Sarra, 2009).Background: The Australian Context

In Australia, Indigenous people are often referred to as victims of their own circumstances, consequently reproducing their isolation and exclusion from education (Sanderson \& Thomson, 2003). In 2007, Indigenous People living in rural and remote areas of Australia were

Questions or correspondence concerning this article may be addressed to:

bf.ewing@qut.edu.au

\begin{abstract}
This paper is a beginning point for discussing what the literature states about parents' involvement in their children's mathematics education. Where possible it will focus on Torres Strait Islander Peoples. Little is known about how Torres Strait Islander parents approach their children's learning of mathematics and how important early mathematics is to mothers. What is known is that is they are keen for their children to receive an education that provides them with opportunities for their present and future lives. However, gaining access to education is challenging given that the language of instruction in schools is written to English conventions, decontextualised and disconnected from the students' culture, community and home language. This paper discusses some of the issues raised in the literature about what parents are confronted with when making decisions about their children's education.
\end{abstract}

less likely than those in urban areas to have completed Year 12 (Australian Bureau of Statistics, 2007). Although improvements in school completions of Indigenous students have been recorded, students aged 15 years and over were still half as likely as non-Indigenous Australians to have completed school to Year 12 in 2006 (23\% compared with 49\%) (ABS, 2007). These relative differences have remained unchanged since 2001. Further, Indigenous students continue to be the most educationally-disadvantaged group particularly within the area of mathematics, performing on national testing two years below their non-Indigenous counterparts (MEECDYA, 2008). When these results are viewed together with student retention rates to Year 12, it is not surprising that the lowest levels of post-compulsory school enrolments are recorded by young Indigenous people (see Lamb, 2009). These statistics are a disturbing particularly when early exit from school has been found to be associated with long term unemployment, "early involvement in the juvenile justice system, and very poor health" (Sanderson \& Thomson, 2003, p. 96). These 


\section{Acknowledgements:}

The author would like to thank Mette Morrison ESL Project Manager Thursday Island State School for challenging me to think how I, as a non-Indigenous person, might work with Torres Strait Island communities to enhance the mathematics learning of their children and to consider how mathematics can be contextualised to culture, community and home language.

social issues are often blamed on the numerous social problems that have manifested within many Indigenous Communities throughout Australia, which unfairly places the focus on the Communities and its people, when it should be on ways to improve the effectiveness of the education that students receive (Aboriginal and Torres Strait Islander Social Justice Commissioner, 2008; Behrendt, 2008; Sarra, 2009).

\section{Aspirations of Indigenous Communities}

Torres Strait Islander parents share the aspirations of Indigenous communities around Australia, that is, they are keen for their children to receive a good education, one that includes literacy and numeracy (Mette Morrison, personal communication, 2008). Whilst there is literature that focuses on education in the Torres Strait Islands (see Shnukal, 2003 for comprehensive bibliography of Torres Strait Education) and women in the Torres Strait Islands (see for example Gaffney, 1989; Osborne, 1997), literature that focuses explicitly on the involvement of women in their children's mathematics education in the Torres Strait Islands is limited. Because of this constraint, the paper will explore beyond this region to develop understandings of how women conceptualize their role in their children's mathematics education. It will also seek explanations of "both ways" environments as describe by Kathryn Priest et al., (2009, p. 118). Briefly, the concept of both ways refers to "a blend of [Western] mainstream and Indigenous cultural knowledge being taught" (Priest et al., 2009, p. 118). This notion will be addressed more in-depth later in this paper. But first, important points need to be explored.

Karen Martin (2008) questions how a Westernized education system accords with Australian Aboriginal and Torres Strait Islander learning systems and acknowledges the influence of parents, extended family, Elders and Community. This matter is also the subject of discussion by the Assembly of First Nations (2005) who are calling for holistic and culturally relevant programs and curriculum.

[C] ultural values, beliefs, traditions and language must be interwoven in all early learning and child care programming. Culture has been acknowledged to play a key role in developing physically and emotionally healthy children with high self esteem that it must become an integral component of the everyday operation of these programs. First Nations clearly stated that Elders need to be involved as advisors and teachers in the development and implementation of First Nations early learning and child care programs. (p. 10)

This call emphasis the need for mainstream education systems to critically reflect on their practices and how curriculum is delivered to Indigenous students. In so doing, considerations of how the students gain access to learning need to be addressed. If students perceive that the content of the curriculum does not link with their daily experiences, culture and home language they are less likely to engage in what they are expected to learn. The Assembly places significant importance on respecting and valuing the diversity of First Nations Communities, so that their children live healthy and successful lives.

In their report of The School Readiness of Australian Indigenous Children, McTurk, Nutton, Lea, Robinson and Carapetis (2008) highlight the heterogeneity of Indigenous cultures. Indigenous people live across different geographical locations and live different lifestyles in communities. However, what is homogeneous is that they share aspirations for their children (Mellor \& Corrigan, 2004; Yunupingu, 1997). That is, Indigenous families want their children to access quality education so that they can gain the knowledge, skills and capacity to succeed in education, employment and in their present and future lives. This does not mean that they give up their cultural identity. Indigenous parents see as paramount that their children's cultural identities as Indigenous people are sustained and maintained (Lester, 2004 cited by Priest, 2005). Therefore an awareness of "the complex and delicate nature of the social and cultural issues at play within and between these communities is critical" (Clancy \& Simpson, 2002, p. 54-55).

\section{Western Mainstream Education and the Rec- ognition of Cultural Identity}

Veronica Arbon (2008) challenges the assumptions underpinning Western mainstream education which purports to recognize Aboriginal and Torres Strait Islander children's cultural identity. She questions how such an education can bring about successful outcomes when it does not recognize Indigenous knowledge systems, cultures and home languages. In concert with Arbon, 
Kathryn Priest (2005) asks how a mainstream education curriculum written to English conventions provides Aboriginal and Torres Strait Islander children with the knowledge and skills to participate in daily social life, if it does not recognize their cultural identity. Priest (2005) and Arbon (2008) state that Western education is now brought into question with calls for "both ways" education, that is, where mainstream knowledge and practices are blended with Indigenous cultural knowledge of learning. Taylor (2003) explains this further by stating that both ways education must work within an "intercultural space" (p. 45). That is,

... the meeting of two distinct cultures' through
processes and interactions which retain the
integrity and difference of both cultures and which
may involve a blending of elements of both cultures
but never the domination of one over another. (p.
45 )

Therefore, it is crucial that cultural knowledge and experiences of Indigenous people are valued and respected and given the currency in the same way that non Indigenous knowledge is for both ways education to work.

The documents Preparing the Ground for Partnership (Priest, 2005), The Indigenous Education Strategic Directions 2008-2011 (Department of Education, Training and the Arts, 2007) and the National Goals for Indigenous Education (Department of Education, Employment and Work Relations, 2008) provide explicit ways to integrate Indigenous cultural knowledge and mainstream knowledge so that Indigenous children receive the best possible literacy and numeracy education to enhance their opportunities for education, training and employment.

Key themes from the above documents include the need to provide children with the best start to education and the importance of contextualizing literacy and numeracy to their community and culture (see Priest, 2005 for a detailed review). Here, community is described "a culture that is oriented primarily towards the needs of the group. This cultural orientation perceives that the whole community must be strong in order to adequately meet the needs of the individual" (Priest, 2005, p. 12). Karen Martin (2005) describes culture as:

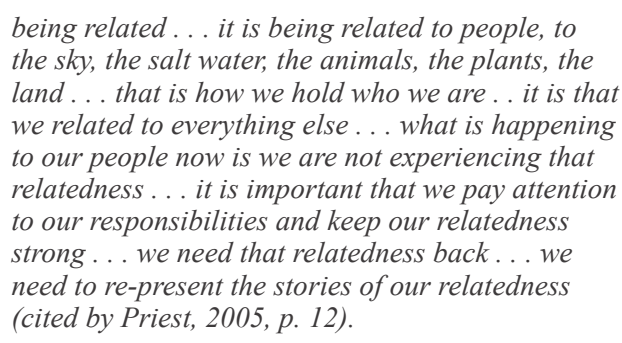

Put another way, Martin Nakata (2007b) states that contextualizing to culture is about that which already exists, that is, Torres Strait Islander community, cultural context and home languages (including the sky, the sea, the land and spiritual values) and "Indigenous knowledge systems" (Nakata, 2007a, p. 2).

Ezeife (2002) cites the work of Hollins (1996) who states that Indigenous people belong to "high-context culture groups" (p. 185). These groups are regarded as adopting a holistic, top-down approach to processing information which is situated in the environment within which they interact. Low context groups adopt a hierarchical and development approach from the bottom up to process information and to construct meaning. Indigenous children who use holistic thought processing are more likely to be disadvantaged in Western mathematics classrooms that adopt a bottom up approach. This is because of the way mathematics is presented to learners, that is, as hierarchical and broken into parts with minimal connections made between concepts and Indigenous children's culture and community (Ewing, 2008). Mathematics, then, potentially conflicts with how they learn. If this divergence is to change, the curriculum needs to be made more culturally-sensitive as well as environmentally and community orientated so that parents can be involved in their children's learning.

\section{A Struggle for recognition}

Kathryn Priest (2005) states that for many years, Indigenous women around Australia have struggled with gaining recognition for their cultures' child learning practices. A contributing factor to this issue is the typical characterizations, or the Westernized view of Indigenous women's involvement in their children's education. Such involvement has characterized Indigenous women as lacking interest in their children's education. Indeed, the portrayal of parents as problems to be overcome and as uninvolved in their children's learning, upholds a particular view of parent participation in education (Jackson \& Remillard, 2005). Now, Indigenous women in Australia are speaking out about what they want for their children, calling for recognition of their cultural knowledge and to be treated "on an equitable basis with '[W] estern' culture” (Priest, 2005, p. 19). In citing the work of the Warrki Jarrinjaku ACRS Project Team (2002) Priest explains that there is a

$$
\begin{aligned}
& \text { growing recognition of the need to have a 'both } \\
& \text { ways' approach to service design and delivery } \\
& \text { (Warrki Jarrinjaku ACRS Project Team 2002). } \\
& \text { An ideal 'both ways' environment places equal } \\
& \text { value and respect on quality of practices from both } \\
& \text { Kardiya (non-Aboriginal) and Anangu and Yapa } \\
& \text { (Aboriginal) cultures. (p. 123) }
\end{aligned}
$$

Whilst there is a growing recognition of Anangu and Yapa cultural knowledge, more work in the wider society 
is needed so that Indigenous knowledge is recognized, respected and learned. (Priest, 2005). For Indigenous women, this issue is not isolated to Australia.

In a study of African American mothers' involvement in their children's mathematics education Jackson and Remillard (2005) found that such characterizations have a strong tendency to privilege traditional Westernized practices of education and schooling. As a consequence of stereotypical views of parental involvement in their children's education, the mothers were confronted with challenges in relation to their children's education. This did not mean that the parents were not involved in their children's learning. The parents took it upon themselves to create opportunities to support their children outside of school. By thinking proactively and strategically, the parents were strong advocates for their children's futures and for the opportunities they wanted them to experience in their adult lives. They used their daily lives and family activities as spontaneous opportunities to engage in discussions about mathematics and its associated language, both informal and formal.

\section{The Language of Mathematics}

Previous discussions have emphasized both ways learning environments and the importance of recognizing and valuing Aboriginal and Torres Strait Islander Peoples' cultural knowledges culture and home languages. Such recognition by non Indigenous people is crucial if they are to work with Indigenous Peoples in their communities to enhance mathematical education of Indigenous children and young people.

It is crucial is that Aboriginal and Torres Strait Islander children be provided with quality education that recognizes, in explicit and implicit ways, their culture, community and home language and that these important aspects are made visible in all areas of children's learning. Indigenous children's culture may be predominately oral and communicated in context, and therefore must be recognized as such by educators as is important (Priest, 2005).

The significance of recognizing oral language is highlighted by Paul Herbert (2008) in his presentation at the World Indigenous Peoples Conference on Education,

Language is the conveyor of culture, through culture we add meaning to things based on symbols. When language disappears our symbols go with it leaving a group of people searching for symbolic meaning. These symbols are what we identify ourselves with. Without these symbols we are to an extent lost.

Learning mathematics that is connected with children's culture and home language provides them with access for further learning and how they identify themselves as learners in communities. When it is disconnected from their culture and home language learning is less likely to occur. A strong point made in Shirley Brice Heath's (1983) work emphasizes that from when we are infants, language determines how we come to know and to be in the world. It binds communities, parents and children together "the adults which the children will one day become repeat the processes with the next generation of children" (Zeegers, Muir \& Lin, 2003, p. 55). What happens then when children are required to speak Standard Australian English in classrooms instead of their home language?

\section{The Official Language of Instruction}

As the official language of instruction, English is learned by Torres Strait Islander children as a second, third or fourth language (Shnukal, 2002). It dominates the Torres Strait Curriculum which is written to English conventions even though it is being perceived by students as a "foreign language expressing alien and uncomfortable modes of thought" (Shnukal, 2002, p. 12). This point raises the question: how can children find meaning in the symbols of Standard Australian English when their first languages are more likely to be Kala Lagaw Ya, Meriam Mir or Yumplatok?

The mathematics curriculum implemented in Queensland is written and delivered in all classrooms in Standard Australian English (Queensland Studies Authority, 2004). However, it is perceived by students in the Torres Strait Island schools as a foreign language (Shnukal, 2002). Mathematics learning is further confounded by curriculum content and material that is out of context and lacking practical purpose and connections to the children's culture and environment thus further reinforcing the view of mathematics curriculum and the conventions it is written too as a foreign language.

Anthony Ezeife (2002) states that irrelevant material and Indigenous children's culture and environment would surface and influence the children's learning. He explains,
If the instructional method favours the learning styles of students from Western cultures (as seems to be the case in contemporary formal school settings), then these students would perform quite well, while the performance of the disadvantaged students from indigenous cultures would not be as good. However, if indigenous students are given the opportunity to learn through an instructional medium that favours their learning or cognitive styles, then the likelihood is that learning would be facilitated and enhanced. (Ezeife, 2002, p. 180)

A more culturally sensitive way to enhance Indigenous children's learning would be to educate using culturally and environmentally based education that links 
directly with their culture. In this way, children have the incentive to learn for understanding because they can find meaning and links to their own cultures, their home languages and in the symbols used.

For Indigenous children, the mathematical concept may not be the difficulty; rather, it may be the language that is used to express it. For example, two categories of common nouns in English cause difficulty for Torres Strait Creole speakers (Schnukal, 2003, p. 55).

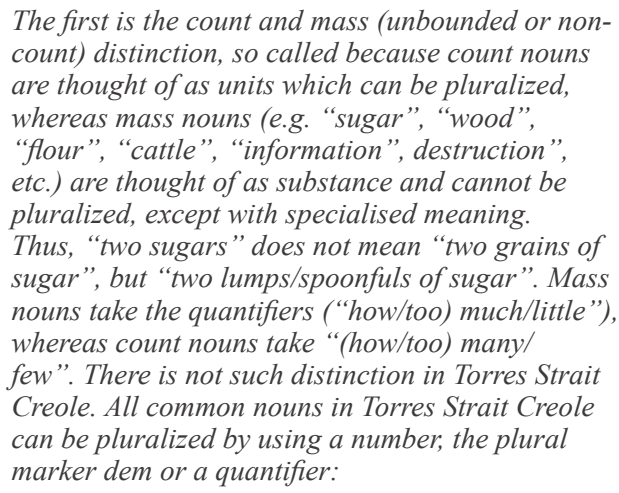

Children who are speakers of Yumplatok are more than likely unaware of the circumstances with which English nouns can and cannot be pluralized and are uncertain of which quantifier to use (Shnukal, 2003). This uncertainty is likely to be influential to how they come to learn formal mathematics that is written and spoken using Standard Australian English conventions. To further illustrate, puffing up shoulders and stating "he's big this kind way" means tall, while stating "I go . . I go, go . . . I go, go, go", means "I went a very long way" (Nakata, 2002). Again, the problem may not be a mathematical or cultural issue, but rather, a language issue. Therefore, it is about having a specialized understanding of how children express their world as they see themselves in it - with verbalization as the key to understanding concepts rather than simply having them manipulate objects that are not context related (Nakata, 2002; Shnukal, 2002). Torres Strait islander children require explicit teaching through interactions with their teacher, other children and adults so they become aware of the different grammatical structures between their language and of those in Standard Australian English.

\section{Concluding comments}

Where possible this paper has discussed the aspirations that Torres Strait Islander parents have for their children. It has also emphasized the significance of recognizing the cultural identity and home language of Australian Aboriginal and Torres Strait Islander communities. This recognition by mainstream education is crucial if both ways education is going to succeed and further, if Indigenous children are going to be able to access further education, training and employment. This paper takes the position that Torres Strait Island children's learning of mathematics can be enhanced if there is an integration of Torres Strait Island cultural knowledge into mainstream western education. Many research documents cite that the mathematics that Indigenous children are learning in school is isolated, disconnected and of little or no relevance to their daily life, their culture and home language. Whilst some effort is being made, more is needed to enhance the lives of young Torres Strait Islander children and to recognize the child learning practices of their parents.

\section{Contributors' Bio}

Bronwyn Ewing is a mathematics education researcher at QUT specializing in the pedagogy of mathematics classrooms from the early years to VET contexts. She has a special interest in the teaching and learning of mathematics to Aboriginal and Torres Strait Islander students and the role of Torres Strait Islander women in their children's prior-to-school mathematics education.

\section{Reference}

Aboriginal and Torres Strait Islander Social Justice Commissioner. (2008). Building a sustainable national Indigenous representative body - Issues for consideration. An Issues Paper prepared by the Aboriginal and Torres Strait Islander Social Justice Commissioner, in accordance with section 46C(1)(b) of the Human Rights and Equal Opportunity Commission Act 1986 (Cth). Retrieved 11/08/09, from http://www.hreoc.gov.au/Social_Justice/repbody/repbody paper2008.pdf.

ABS. (2007). Schools Australia Catalogue No. 4221.0. Retrieved 11/08/09, from http://www.abs.gov.au/AUSSTATS/ abs@.nsf/0/84829036269D0245CA2573FD00112545?Ope nDocument.

Arbon, V. (2008). Arlathirnda Ngurkarnda Ityyirnka BeingKnowing-Doing. Brisbane: PostPressed.

Assembly of First Nations. (2005). First Nations early learning and child care action plan. Retrieved 12/02/09, from http:// 


\section{Torres Strait Parents Involvement in their Children's Mathematics Learning}

www.afn.ca/cmslib/general/elcc.pdf.

Behrendt, L. (2008). Warrane Lecture 2008: Achieving Social Justice for Aboriginal People in a Civil Society. Retrieved 20/10/08, from http://www.abc.net.au/news/opinion/ speeches/files/20081016behrendt.pdf.

Clancy, S., \& Simpson, L. (2002). Literacy learning for Indigenous students: Setting a research agenda. Australian Journal of Language and Literacy, 25(2), 47-64.

Department of Education Employment and Workplace Relations. (2008). National Goals for Indigenous Education. Retrieved 2/10/08, 2008, from http://www.dest.gov.au/ sectors/indigenous education/policy issues reviews/ national goals for indigenous education.htm

Department of Education Training and the Arts. (2007). Indigenous education strategic directions 2008-2011. Retrieved 2/10/08, 2008, from http://education.qld.gov.au/strategic/ planning/pdfs/indig-strat-directions.pdf.

Ewing, B. (2008). Discourse, identity and community: Fortythree early school leavers' accounts of their experiences of mathematics learning in two contexts. In: Australian Association for Research in Education 2008 : Changing climates - Education for Sustainable Futures, 30th November - 4th December, 2008, Queensland University of Technology.

Ezeife, A. N. (2002). Mathematics and culture nexus: The interactions of culture and mathematics in an Aboriginal classroom. International Education Journal, 3(2), 176-187.

Gaffney, E. (1989). Somebody now. Canberra: Aboriginal Studies Press.

Heath, S. B. (1983). Ways with words language, life, and work in communities and classrooms: Cambridge University Press.

Herbert, P. (2008). WIPC:E 2008 - the World Indigenous Peoples' Conference on Education.

Hollins, E. R. (1996). Culture in school learning: Revealing the deep meaning. Mahwah, New jersey: Lawrence Erlbaum Associates.

Jackson, K. R., J. (2005). Rethinking parent involvement: African American mothers construct their roles in the mathematics education of their children. School community journal, 15(1), 51-73.

Lamb, S. (2009). Modelling of post compulsory schooling enrolments. Retrieved 11/08/09, from http://www.cgc. gov.au/ data/assets/file/0014/17024/2009 - Modelling_of_post-compulsory_students.pdf.

Lester, J. (2004, November). Sydney Morning Herald. http:// www.smh.com.au.

Martin, K. (2008). Please knock before you enter: Aboriginal regulation of Outsiders and the implications for researchers. Brisbane: PostPressed.

McTurk, N., Nutton, G., Lea, T., Robinson, G., \& Carapetis, J. (2008). The school readiness of Australian Indigenous children: A review of the literature. Darwin: Charles Darwin University, Northern Territory.
MEECDYA (2008). National assessment program literacy and numeracy: Achievement in reading, writing, language conventions and numeracy. Journal. Retrieved from http:// www.mceecdya.edu.au/verve/ resources/NAPLAN_2008Full Report.pdf.

Mellor, S. C., M. (2004). The case for change: A review of contemporary research on Indigenous education outcomes. Retrieved 12/01/09, 12/01/09, from http://search.informit. com.au/fullText; $\mathrm{dn}=324175841163329 ;$ res=IELHSS.

Morrison, M. (2008). English as Second language Project Officer, Tagai State College, Thursday Island.

Nakata, M. (2007a). The Cultural Interface. The Australian Journal of Indigenous Education, 36, 7-14.

Nakata, M. (2007b). Disciplining the savages: Savaging the disciplines. Canberra: Aboriginal Studies Press.

Osborne, E. (1997). Torres Strait Islander Women and the Pacific War. Canberra: Aboriginal Studies Press.

Priest, K. (2005). Preparing the ground for partnership: Exploring quality assurance for Aboriginal and Torres Strait Islander child care: A literature review and background paper. Canberra: Department of Family and Community Services.

Priest, K., et al. (2009). Warrki Jarrinjaku "Working Together Everyone and Listening": Growing Together as Leaders for Aboriginal Children in Remote Central Australia. 16(1), 117-130.

Queensland Studies Authority. (2004). Mathematics: Years1 to 10 syllabus. Brisbane: Queensland Studies Authority.

Sanderson, V., \& Thomson, P. (2003). Towards a just Indigenous education: a continuing challenge for state schooling. In A. Reid., and P. Thomson (Eds.), Towards a public curriculum (pp. 95-120). Flaxton: PostPressed.

Sarra, C. (2009). New narrative tells of brighter future together. Retrieved 11/08/09, from http://www.theaustralian.news. com.au/story/0, 25897610-28737,00.html.

Shnukal, A. (2002). Some language-related observations for teachers in Torres Strait and Cape York Peninsula schools. The Australian Journal of Indigenous Education, 30(1), $8-24$.

Shnukal, A. (2003). Bibliography of Torres Strait Education. The Australian Journal of Indigenous Education, 31, 77-80.

Taylor, R. (2003). An Indigenous perspective on evaluations in the inter-cultural context: how far can one throw a Moree boomerang? Evaluation Journal of Australasia, 3(2).

Yunupingu, M. (1997). 'Double power', speech delivered at the Language Learning and Culture: Unsettling Certainties Conference, Darwin.

Zeegers, M., Muir, W., \& Lin Z. (2003). The primacy of the mother tongue: Aboriginal literacy and non-standard English. The Australian Journal of Indigenous Education, 32, 51-60. 